\title{
A Comparative Study of Different Types of Cultural NPOs in Terms of the Contract Relationships, Public Service Motivation, satisfaction and Work Performance of their Public Web Portal
}

\author{
Youngran Hyun* \\ *Ewha Institute for Social Science, Ewha Womans University, \\ 120-750, Seoul, Korea \\ hyran2@hanmail.net
}

\begin{abstract}
The purpose of this study is to compare Korean cultural centers and museums' contract relationships and public service motivation (PSM) for participating in government portals. Korean NPOs participate in the Culture Portal constructed by the Korean Central Government. We investigate the influence of contract relationships and PSM on the user-satisfaction and work performance of these public web portals by comparing cultural centers and museums. A survey was used to collect data from NPOs participating in Korea's public Cultural Portal. Data was collected from a survey of 101 cultural centers and 44 muesums paticipating in Korea's Cultural Portal. This data was organized according to a 5 point scale. According to comparative data analysis, there are a statistically significant difference in manpower support. The financial support, usersatisfaction of museums is higher than cultural centers, but the PSM, work performance of culture center is higher than museums.
\end{abstract}

Keywords: Government support, Administrative regulation, NPOs public service motivation, Satisfaction, Work performance, Modern museums, Culture center

\section{Introduction}

In today's rapidly changing society there is a trend towards providing public services through collaborative projects between governments and NPOs. According to information system theory and inter-organizational relationship theory, public web portal collaboration is important for digitalized public services and could contribute to contemporary arts and culture. Thus the collaboration between government and cultural NPOs has become important for providing public services.

The Korean Government constructed the Culture Portal (www.culture.go.kr) by means of a new digital collaborative method which aggregates public organizations' varied digitized knowledge of local arts and cultures. Cultural NPOs, museums and cultural centers, participate in the Cultural Portal by sharing their information through it [1].

In this context, we compared NPOs' contracts with government with their PSM. Because most of the cultural NPOs participating in the Cultural Portal are cultural centers and museums we focused on comparing these two. Also even though cultural centers and museums differ in their policy programs and strategies, they have similar structures. Korean local Cultural Centers area non-profit organizations that conduct cultural and social education programs to promote local culture. Korean local museums are institutions that collect and display historical and contemporary art objects They have close relationships with governments and they are supported by government support. Along these lines our comparison of cultural centers and museums participating in the Korean

Received (June 18, 2017), Review Result (August 24, 2017), Accepted (August 30, 2017)

* Corresponding Author 
Cultural Portal contributes to understanding the effects of PSM and contract relationship. Thus we compared the contracts, PSM, user satisfaction and work performance of cultural centers and museums participating in the Korean Cultural Portal.

\section{Contract Relationships between Government and NPOs}

Recently, there has been increasing emphasis on NPOs providing public services through government contracts. These contracts are composed of support and administrative regulation. Government support (financial, manpower and IT support) helps NPOs with their organizational problems by increasing their planning capacities and performance [2]. In this way, government support promotes NPOs cooperative performance in government projects. These service contracts between the government and NPOs also have the advantage of stimulating the active participation of NPOs in the policy process. However, government administrative regulation, which accompanies support, is a burden for NPOs. Government regulation is a policy tool designed to strengthen the financial accountability of NPOs. Government support to NPOs is contingent on governments managing NPOs' finances through reports, evaluations and audits. The procedures of government regulation of NPOs' finances negatively influences the performance of NPOs [3].

In addition, there may be differences in degree of the government support (financial, manpower, IT) and regulation according to organizational type. Cultural centers conduct local cultural projects to promote the local culture, and, thus they receive more financial support than museums. Museums collect and display art objects, and, thus they receive more manpower support than cultural centers. Even though they have similar missions, cultural centers and museums have different programs and strategies. Thus, following these differences in support our hypothesis was the following: the degrees of support and regulation will differ according to organization type (culture centers versus museums).

Hypothesis1: there will be a difference in government financial support, manpower support, and information support between cultural centers and museums.

Hypothesis2: there will be a difference in administrative regulations between the culture centers and the museums.

\subsection{NPOs' Public Service Motivation (PSM)}

NPOs have an inherent motivation to provide public services, which is vital for their collaboration with government. In particular, when NPOs participate in the government web portal projects, NPO PSM plays a crucial role in determining these projects' performance. Generally, NPO PSM is NPOs' willingness to contribute to communities. But in this context, it has a more specific meaning which also includes NPOs' commitment to the government policy process; it is their altruistic attitude toward participating in government activities for the public[4 ]. Thus, NPO PSM is important for NPOs to be willing to provide knowledge to government web portals voluntarily. Because the Korean Culture Portal's knowledge is provided by various NPOs, NPO PSM is vital. Thus NPO PSM helps public web portals voluntarily provide knowledge to the public. For both cultural centers and museums PSM is essential. However, because cultural centers and museums have different organizational structures, their PSM needs to be examined separately.

Hypothesis3: there is a difference in PSM are according to type of NPO.

\subsection{NPO Satisfaction and Work Performance with Public Web Portals}

This research conducted a comparative analysis of cultural NPOs' (cultural centers and museums) user-satisfaction and work performance with a public web portal. The performance of public web portals was understood in terms of two variables, user satisfaction and work performance. First, user satisfaction of public web portals consists 
of knowledge, service, and system[5]. The Culture Portal's knowledge consists of modern art and performing arts, service means user friendliness and system means access speed. Second, the work performance of public web portals consists of the user benefits of simplified of work, reduced work time, increased work capacity, and enhanced work efficiency[5]. Recently, user satisfaction and work performance of public web portals has become an important variable for inter-organizational information systems. Museums and cultural centers have different goals and structures. Generally, museums specialize in modern and historical art. And cultural centers, which tend to be more popular provide various genres of local culture, especially to local senior citizens. Thus users of cultural centers and museums have difference of perceptions of the satisfaction and work performance of participating public web portals. This is because users of cultural centers and museums have different organizational situations and expectations. Thus cultural centers and museums need to be examined separately.

Hypothesis4: there are differences in the user satisfaction of cultural centers and museums.

Hypothesis5: there are differences in work performance of cultural centers and museums.

\section{Data and Measurement}

We conducted a survey to get data on these cultural NPOs. Between December 2011 and February 2012, we interviewed the CEOs of 144 cultural centers and museums participating in Korea's Culture Portal. We compared them by using an arithmetic mean and added the harmonic mean because there was a large difference between the sample sizes of cultural centers (101) and museums (43). This paper attempts a comparison of these NPOs' PSM by comparing these two types of NPOs' contracts with governments (consisting of support and regulation), user satisfaction and work performance. Measurement of financial support and administration regulation was derived from 'Law and Regulation of Subsidies Budget and Management' (Executive order No.2283)'. Measurement of manpower support was based on The Korean Arts Council's 'Expert Manpower Evaluation Project' (2009). Measurement of IT support was adapted from GilGarcia \& Pardo (2005) and Song (2006). Measurement of user-satisfaction and work performance was adapted from Bailey \& Pearson $(1983,2003)$ and DeLone \& McLean (2003). Measurement of NPO PSM was adapted from Pretty et al. (1995) and Szulanski $(1996,2004)[3-6]$.

\section{Analysis and Results}

\subsection{Government Support and Administrative Regulation}

Table 1 is a comparison of the PSM, government support, administrative regulation of all the interviewed NPOs participating in the Culture Portal. The data analysis shows that there were some significant differences according to type of organization. Overall, the degree of financial support received from the central and local governments was higher for museums than cultural centers. 
Table 1. Government Support and Administrative Regulation

\begin{tabular}{|c|c|c|c|c|c|}
\hline & Type & $\mathrm{N}$ & Mean & S.D. & $\mathrm{F}$ \\
\hline \multirow{4}{*}{$\begin{array}{l}\text { Financial } \\
\text { Support }\end{array}$} & Cultural Center & 101 & 11.323 & 16.14937 & $.118(.732)$ \\
\hline & & & & & \\
\hline & Museum & 43 & 12,4351 & 21.2091 & \\
\hline & Total & & 11.6550 & 17.74139 & \\
\hline \multirow{4}{*}{$\begin{array}{l}\text { Manpower } \\
\text { Support }\end{array}$} & Cultural Center & 101 & 0.5181 & 25.86681 & 69.098 \\
\hline & & & & & $* * *$ \\
\hline & Modern Museum & 43 & 20.1630 & 23.27907 & \\
\hline & Total & & 6.3843 & 15.76903 & \\
\hline \multirow{4}{*}{$\begin{array}{l}\text { IT } \\
\text { Support }\end{array}$} & Cultural Center & 101 & 1.2521 & .48618 & $.000(.983)$ \\
\hline & & & & & \\
\hline & Modern Museum & 43 & 1.2503 & .50896 & \\
\hline & Total & & $1.2515(1.1448)$ & .47643 & \\
\hline \multirow{3}{*}{$\begin{array}{l}\text { Administrativ } \\
\text { e Regulation }\end{array}$} & Cultural Center & 101 & $3.0281(2.7329)$ & .77927 & .034 \\
\hline & Museum & 43 & $3.0533(2.8398)$ & .67635 & $(.855)$ \\
\hline & Total & & $3.0355(2.7640)$ & .74776 & \\
\hline
\end{tabular}

$* \mathrm{p}<.05 * *, \mathrm{P}<.01 * * *, \mathrm{P}<.001, \quad(\quad)$ : harmonic mean.

Both cultural centers and museus' financial support was between $11 \%$ and $12 \%$. In terms of The Korean Goverment's budget, the amount provided for culture budget has increased recently: .31(2010)-> )->.0.32(2012)->0.36(\%)(2013)->0.64(\%)(2014). But Korea's Cultural Budget is below the average for OECD countries: average 1.30\%, lowest $.07 \%$, and highest $3.28 \%$. The Korean Cultural Budget consists of culture (including arts), sports and tourism. Thus the financial support going to these NPOs comes from the part of the cultural budget devoted to culture. According to the Scheffé test, manpower support varied significantly according to the type of organization. The degree of manpower support received from government was higher for museums $(20.1630 \%)$ than cultural centers $(0.5181 \%)$. Cultural centers receive so little manpower support because they depended on local government subsides. They tend to not apply for manpower support which controlled by the Arts Council of Korea. The differences in degrees of IT support and administration regulation were not significant.

\subsection{NPO 's Public Service Motivation}

NPOs' inherent PSM is an important factor for their collaboration with governments for providing public services. Recently, NPO PSM is critical for increasingly common collaborative projects. Considering all of the measured items, there are differences according to organizational type. 
Table 2. NPO 's Public Service Motivation

\begin{tabular}{|c|c|c|c|c|}
\hline & Survey Item & Total & $\begin{array}{l}\text { Culture } \\
\text { Center }\end{array}$ & Museum \\
\hline \multirow{6}{*}{$\begin{array}{c}\text { NPOs } \\
\text { public } \\
\text { service } \\
\text { motivati } \\
\text { on }\end{array}$} & $\begin{array}{l}\text { 1.Our organization is linked to the Cultural Portal in order to contribute to the } \\
\text { development of Koreancultureandarts }\end{array}$ & $\begin{array}{c}3.2459 \\
(3.0539)\end{array}$ & $\begin{array}{l}3.2635 \\
(\mathbf{3 . 1 2 2 1})\end{array}$ & $\begin{array}{l}3.2044 \\
(2.9049)\end{array}$ \\
\hline & $\begin{array}{l}\text { 2. Our organization is linked to the Cultural Portal because of our keen interest } \\
\text { intheCultural Ministry's policies andprojects. }\end{array}$ & $\begin{array}{c}\mathbf{3 2 4 3 6} \\
(\mathbf{3 . 0 3 2 7})\end{array}$ & $\begin{array}{l}\text { 3.2610 } \\
(\mathbf{3 . 0 3 8 5})\end{array}$ & $\begin{array}{l}3.2029 \\
(3.0192)\end{array}$ \\
\hline & $\begin{array}{l}\text { 3. Our organization is linked to the Cultural Portal because we want the Cultural } \\
\text { Ministry'sprojects to performbetter as a cultural arts organizations. }\end{array}$ & $\begin{array}{r}3.4482 \\
(3.2930)\end{array}$ & $\begin{array}{l}\text { 3.4772 } \\
(\mathbf{3 . 3 3 2 4})\end{array}$ & $\begin{array}{l}3.3799 \\
(3.2040)\end{array}$ \\
\hline & $\begin{array}{l}\text { 4. Our organization is linked to the Cultural Portal because we are actively helping the } \\
\text { Cullural Ministry as a cultural arts organization. }\end{array}$ & $\begin{array}{l}3.4683 \\
(3.2196)\end{array}$ & $\begin{array}{l}3.4563 \\
(3.2435)\end{array}$ & $\begin{array}{c}3.4967 \\
(3.1651)\end{array}$ \\
\hline & $\begin{array}{l}\text { 5. Our organization is linked to the Cultural Portal because we will share } \\
\text { our information throughit }\end{array}$ & $\begin{array}{c}3.2327 \\
(\mathbf{3 . 0 3 7 5})\end{array}$ & $\begin{array}{l}\text { 3.2951 } \\
(3.0937)\end{array}$ & $\begin{array}{l}3.086 \\
(2.9132)\end{array}$ \\
\hline & Total & $\begin{array}{c}\text { 3.3277 } \\
(\mathbf{3 . 2 0 9 9})\end{array}$ & $\begin{array}{c}3.3506 \\
(3.2416)\end{array}$ & $\begin{array}{l}3.2740 \\
(3.1376\end{array}$ \\
\hline
\end{tabular}

On average, NPO PSM is higher for cultural centers than museums. But cultural centers have the higher score with items 1 (contribution), 3 (compassion) and 5 (information sharing). Museums have a higher score for item2(interest in the Cultural Ministry's policies and projects.), items 4(helping in the Ministry's policies and projects). Museum have the interest in the government policy and participation. Overall, cultural centers had slightly higher PSM, but the difference was not significant.

\subsection{NPO Satisfaction with Public Web Portals}

Each survey item will be used to compare cultural centers to museums. According to the arithmetic mean, cultural centers service satisfaction, system satisfaction, and overall portal satisfaction were higher than those of museums. However, according to the harmonic mean, museums knowledge satisfaction, service satisfaction, system satisfaction, and overall portal satisfaction were higher than those cultural centers. When taking into account the sample size through use of the harmonic mean, museum satisfaction was higher than cultural center satisfaction.

Table 3. NPO 's Satisfaction with Public Web Portals

\begin{tabular}{|c|c|c|c|c|c|}
\hline Variable & Survey Items & Total & $\begin{array}{l}\text { Culture } \\
\text { Center }\end{array}$ & Museum & \\
\hline \multirow{5}{*}{$\begin{array}{l}\text { User } \\
\text { satisfaction }\end{array}$} & $\begin{array}{l}\text { 1. Our organization was satisfied with the } \\
\text { knowledge information provided by the }\end{array}$ & $\begin{array}{c}2.4889 \\
(2.0542)\end{array}$ & $\begin{array}{l}2.4847 \\
(2.0063)\end{array}$ & $\begin{array}{c}2.4987 \\
(2.1762)\end{array}$ & \\
\hline & $\begin{array}{l}\text { 2. Our organization was satisfied with the } \\
\text { Culture Portal's services. }\end{array}$ & $\begin{array}{c}2.4779 \\
(2.0544)\end{array}$ & $\begin{array}{c}2.4942 \\
(2.0481)\end{array}$ & $\begin{array}{l}2.4398 \\
(2.0692)\end{array}$ & \\
\hline & $\begin{array}{l}\text { 3. Our organization was satisfied with the } \\
\text { Culture Portal's system. }\end{array}$ & $\begin{array}{l}2.5185 \\
(2.0767)\end{array}$ & $\begin{array}{l}2.5453 \\
(2.0688)\end{array}$ & $\begin{array}{l}2.4556 \\
(2.0957)\end{array}$ & \\
\hline & $\begin{array}{l}\text { 4. Our organization was generally satisfied with } \\
\text { the Culture Portal. }\end{array}$ & $\begin{array}{l}2.6471 \\
(2.0915)\end{array}$ & $\begin{array}{l}2.6890 \\
(2.0471)\end{array}$ & $\begin{array}{r}2.5486 \\
(2.2039)\end{array}$ & \\
\hline & Total & $\begin{array}{c}2.5280 \\
(2.1100)\end{array}$ & $\begin{array}{l}2.5531 \\
(2.0831)\end{array}$ & $\begin{array}{l}2.4690 \\
(2.1745)\end{array}$ & \\
\hline
\end{tabular}




\subsection{Work Performance of Public Web Portals}

The work performance of cultural centers is higher than museums according to both the arithmetical and the harmonic mean. This means that there is some resistance to museums using the latest public web portals. This also shows that cultural centers are benefiting more from cultural portals in terms of work performance than museums.

Table 4. Work Performance of Public Web Portals

\begin{tabular}{|c|c|c|c|c|}
\hline $\begin{array}{l}\text { varia } \\
\text { ble }\end{array}$ & Survey Items & Total & $\begin{array}{l}\text { Culture } \\
\text { Center }\end{array}$ & Museum \\
\hline \multirow{4}{*}{$\begin{array}{l}\text { Work } \\
\text { perfor } \\
\text { manc } \\
\text { e }\end{array}$} & $\begin{array}{l}\text { 1.Our organization has reduced our enforcement } \\
\text { cost by using the Cultural Portal. }\end{array}$ & $\begin{array}{l}2.4848 \\
(2.1526)\end{array}$ & $\begin{array}{l}2.5686 \\
(2.2257)\end{array}$ & $\begin{array}{c}2.2882 \\
(1.9984)\end{array}$ \\
\hline & $\begin{array}{l}\text { 2. Our organization has shortened our processing } \\
\text { time by using the Culture Portal. }\end{array}$ & $\begin{array}{c}2.4470 \\
(2.1196)\end{array}$ & $\begin{array}{l}2.5172 \\
(2.1685)\end{array}$ & $\begin{array}{l}2.2821 \\
(2.0130)\end{array}$ \\
\hline & $\begin{array}{l}\text { 3. Our organization's business has increased by } \\
\text { using the Culture Portal. }\end{array}$ & $\begin{array}{l}2.4015 \\
(2.0871)\end{array}$ & $\begin{array}{l}2.4456 \\
(2.1227)\end{array}$ & $\begin{array}{r}2.2979 \\
(2.0080)\end{array}$ \\
\hline & $\begin{array}{l}\text { 4. Our organization's results have increased by } \\
\text { using the Cultural Portal. }\end{array}$ & $\begin{array}{c}2.4470 \\
(2.1144)\end{array}$ & $\begin{array}{l}2.4974 \\
(2.1569)\end{array}$ & $\begin{array}{c}2.3286 \\
(2.0209)\end{array}$ \\
\hline & Total & $\begin{array}{l}2.4451 \\
(2.1452)\end{array}$ & $\begin{array}{l}2.5072 \\
(2.1994)\end{array}$ & $\begin{array}{c}2.2992 \\
(2.0278)\end{array}$ \\
\hline
\end{tabular}

\section{Implications and Discussion}

We performed a comparative study of cultural centers and museums in terms of government contract relationships, NPO PSM of participating government web portals, and these NPOs' satisfaction and work performance. We compared all measured variables. Museums have higher government financial support than cultural centers. Even though cultural centers and museums share similar missions, they have significantly different government manpower support. Cultural centers do not receive much manpower support. Manpower support is important to NPOs, because manpower enhances organizational capacity and organizational productivity. And cultural centers have higher of contribution, public commitment than museum, museum have higher of attraction of policy and compassion. Government try to consider these characteristics to induce the NPOs in policy process.

\section{References}

[1] www.culture.go. kr

[2] L. M. Salamon, "Partners in Public Service", The Johns Hopkins Univ. Press, (1995).

[3] H. Youngran, "The Impact of Government Support and Regulation on Sharing and Utilization of Knowledge Information Resource", Korean Public Administrative Review, vol. 47, (2013), pp. 425-451.

[4] J. L. Perry, "Bringing Society, In: Toward a Theory of Public Service Motivation", Journal of Public Administration Research and Theory, vol. 10, no. 2, (2000), pp. 471-488.

[5] W. H. DeLone and E. R. McLean, "The DeLone and McLean Model of Information System Success: A Ten-year Update", Journal of Management Information Systems, vol. 19, (2003), pp. 9-30.

[6] J. E. Bailey and S. Pearson, "Development of a Tool for Measuring and Analyzing Computer User Satisfaction”, Management Science, vol. 29, (1983), pp. 530-545. 